\title{
The quarry and workshop of Barranco Cardones (Gran Canaria, Canary Islands): Basalt quern production using stone tools
}

\author{
Yurena Naranjo-Mayor ${ }^{1}$, Isabel Francisco-Ortega ${ }^{2}$, Amelia \\ Rodríguez-Rodríguez ${ }^{1}$
}

1. G. I. Tarha. Departamento de Ciencias Históricas. Universidad de Las Palmas de Gran Canaria. Plaza de la Constitución s/n 35003, Las Palmas de Gran Canaria, Las Palmas, Spain.

Email: Naranjo-Mayor: yurena.nm@gmail.com; Rodríguez-Rodríguez: amelia.rodriguez@ulpgc.es

2. G. I. Sociedades Cazadoras-Recolectoras. Departamento de Geografía e Historia. Universidad de La Laguna.

Santa Cruz de Tenerife, Spain. Email: ixa@telefonica.net

\begin{abstract}
:
Querns for grinding cereals were essential in the everyday life of the Pre-European population of the Island of Gran Canaria as their agriculture was based mainly on barley and wheat, cereals processed for the most part in the form of roasted flour. Rotary querns and other grinding stones, nonetheless, have rarely been the object of research in the Canary Islands and the study of their operational sequence of production has only recently been initiated. Volcanic tuff (compact lapilli) was the most commonly quarried rock. Other raw materials such as basalt, and to a lesser extension tephrite, were also worked. Since metal tools were not known in the Canary Islands in Pre-European contexts, all of the stages of extraction and fashioning had to be carried out with stone tools.

This paper analyses the operational sequence, that is, the different phases of the extraction and fashioning techniques of basalt rotary querns based on the recent finds of two quarries located near the coast (Cardones and Cebolla) and a quern manufacturing workshop (Cave 36, Arucas Municipality) in a ravine about $600 \mathrm{~m}$ inland. Traditionally it was thought that the Pre-European population of Gran Canaria fashioned their querns from naturally detached volcanic surface blocks collected in ravines or along the coast. This supposition was based on the idea that the early Canarians were not capable of extracting blocks from bedrock with stone tools. This notion, however, has been proven wrong by the circular extraction negatives on the quarry faces and by finds of stone fashioning tools in the workshop.
\end{abstract}

Keywords: Canary Islands; Gran Canaria; Pre-European period; basalt rotary querns; basalt quarries; fashioning workshop

\section{Introduction and objectives}

The Pre-European period in the Canary Islands began sometime in the first millennium BCE. According to archaeological and genetic data, the archipelago was first populated by

Published by the School of History, Classics and Archaeology, University of Edinburgh ISSN: 2055-0472. URL: http://journals.ed.ac.uk/lithicstudies/

This work is licensed under a Creative Commons Attribution 2.5 UK: Scotland License. 
Berbers from north-western Africa. Yet there is still very little data regarding the geographical origin and the timeframe of the first waves of humans attaining the different islands of the archipelago. The most recent research suggests dates ranging from the 9th century BCE for the Island of Lanzarote (Atoche 2013) and up to the 3rd-4th centuries CE for the other islands (Maca-Meyer et al. 2004; Rodríguez-Rodríguez et al. 2012).

Since the Pre-European population did not possess the resources to produce metal tools, most querns were fashioned with stone tools. The volcanic origin of the archipelago resulted in the availability of different types of eruptive rocks. Grinding stones of different type were hewn from massive grainy rocks such as basalt, vesicular basalt, tephryte and volcanic tuff (compact volcanic ashes). The knapping tools, in turn, were made from hard, coarse rocks such as basalts, trachytes and phonolites. An important local raw material was obsidian, a sort of volcanic glass similar in texture to flint. Although it served for a variety of tools, it did not take part in the quern making process.

Cereals were the staple of Gran Canaria's Pre-European population (Morales 2010; Morales et al. 2014). The island's archaeological record reveals that virtually every settlement or granary possessed their own grinding stones. The granaries in fact were often beyond the settlements in the form of remote caves dug into cliff sides. Our team carried out a research project with the goal of understanding the socio-economic role of grinding stones in Canarian society preceding the Spanish conquest.

Previous research has identified and analysed volcanic tuff quarries producing rotary querns (Rodríguez-Rodríguez et al. 2006a: 115-141; 2010). Yet the extraction of basalt for rotary querns, a rock that is harder and more demanding to work, has only recently been identified. Contrary to the tuff quarries, basalt quern extraction sites show no evidence of working debris. This may be due to their location along the bed of the ravines where the debitage and discarded tools may have been removed during flash flooding. Despite this absence, we are able to interpret the extraction marks on the quarry faces of the basalt outcrops as they are identical to those of volcanic tuff quarries studied elsewhere.

Furthermore, a recent archaeological rescue operation along the edge of the Barranco Cardones, a ravine in the Municipality of Arucas, has identified a workshop specialised in the fashioning of vesicular basalt rotary querns and other grinding implements (Figure 1). The site, in a cave near one of the basalt quarries, is an exceptional find as it is the first case in Gran Canaria that proves that cylindrical roughouts were first extracted in quarries and then could be transported to a workshop elsewhere to be shaped and finished.

This paper therefore presents the results of the analysis of the lithic artefacts associated with the extraction and fashioning of rotary querns. This work is one of two PhD studies focusing on grinding stones (Naranjo-Mayor, ongoing) and other types of knapped stone tools (Francisco-Ortega 2016: 166-167) on the Island of Gran Canaria. The objectives of the current research are as follows:

- To compare the extraction techniques of volcanic tuff and vesicular basalt quarries.

- To reconstruct the operational sequence for making vesicular basalt querns, from the quarry to the fashioning workshop.

- To identify the quern extraction and fashioning tools and their characteristic forms when they are resharpened or broken.

- To identify the tool marks on the roughout surfaces and to link the marks with the different phases of the operational sequence of quern production.

\section{Method and materials}

The preliminary findings of our research have identified three main types of grinding stones that can be classified by their morphology: (1) rotary querns, (2) variations of saddle 
querns and (3) mortars (Figure 2). In addition to these implements, there is a wide range of uncharacteristic, irregular shaped, and less well-made stones that could have also served as grinders. Yet the most common product is the hand-driven rotary quern (Naranjo-Mayor \& Rodríguez-Rodríguez 2015; 2016).

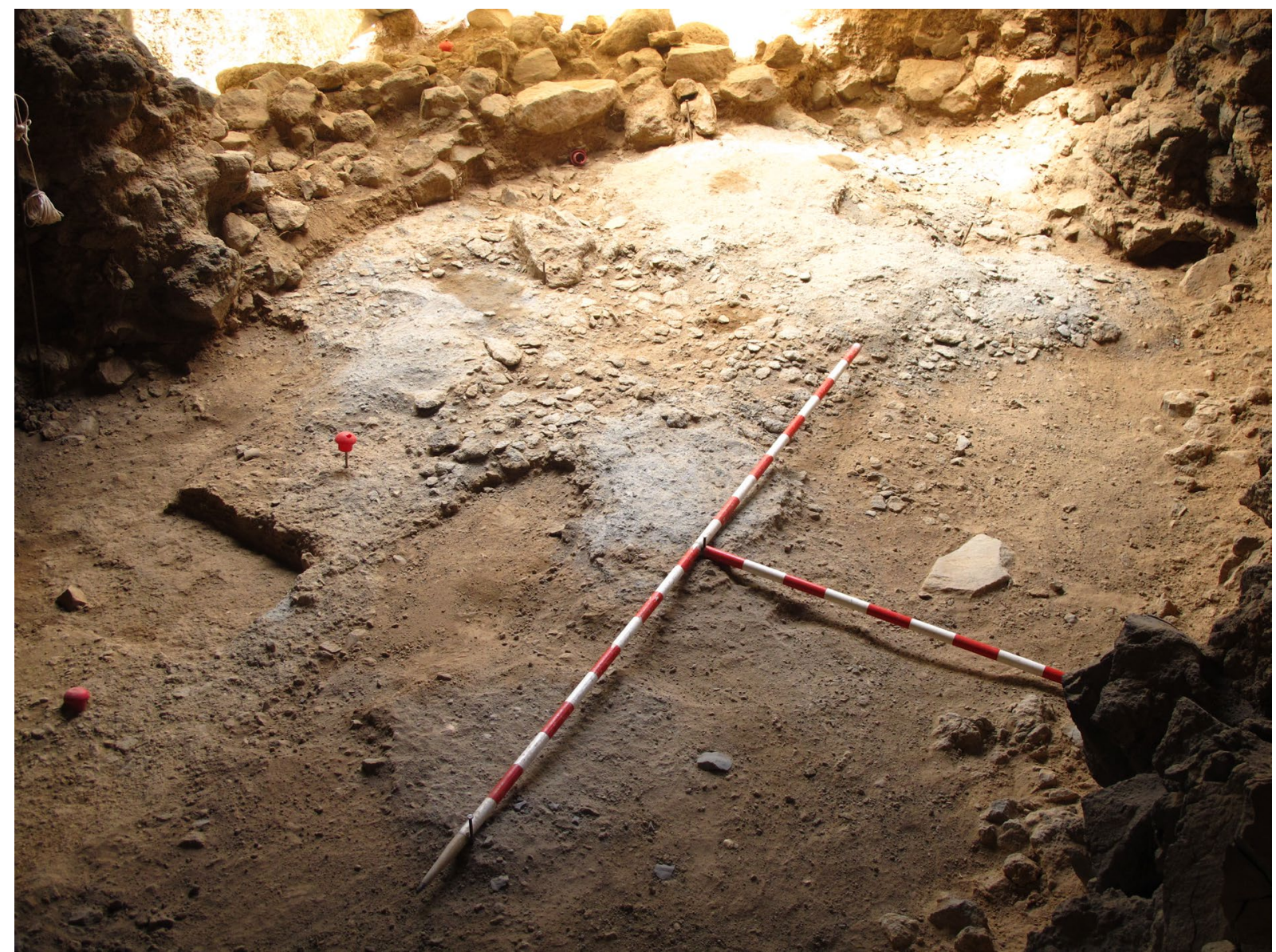

Figure 1. View of the Barranco Cardones rotary quern workshop (Cave 36, Arucas, Gran Canaria).
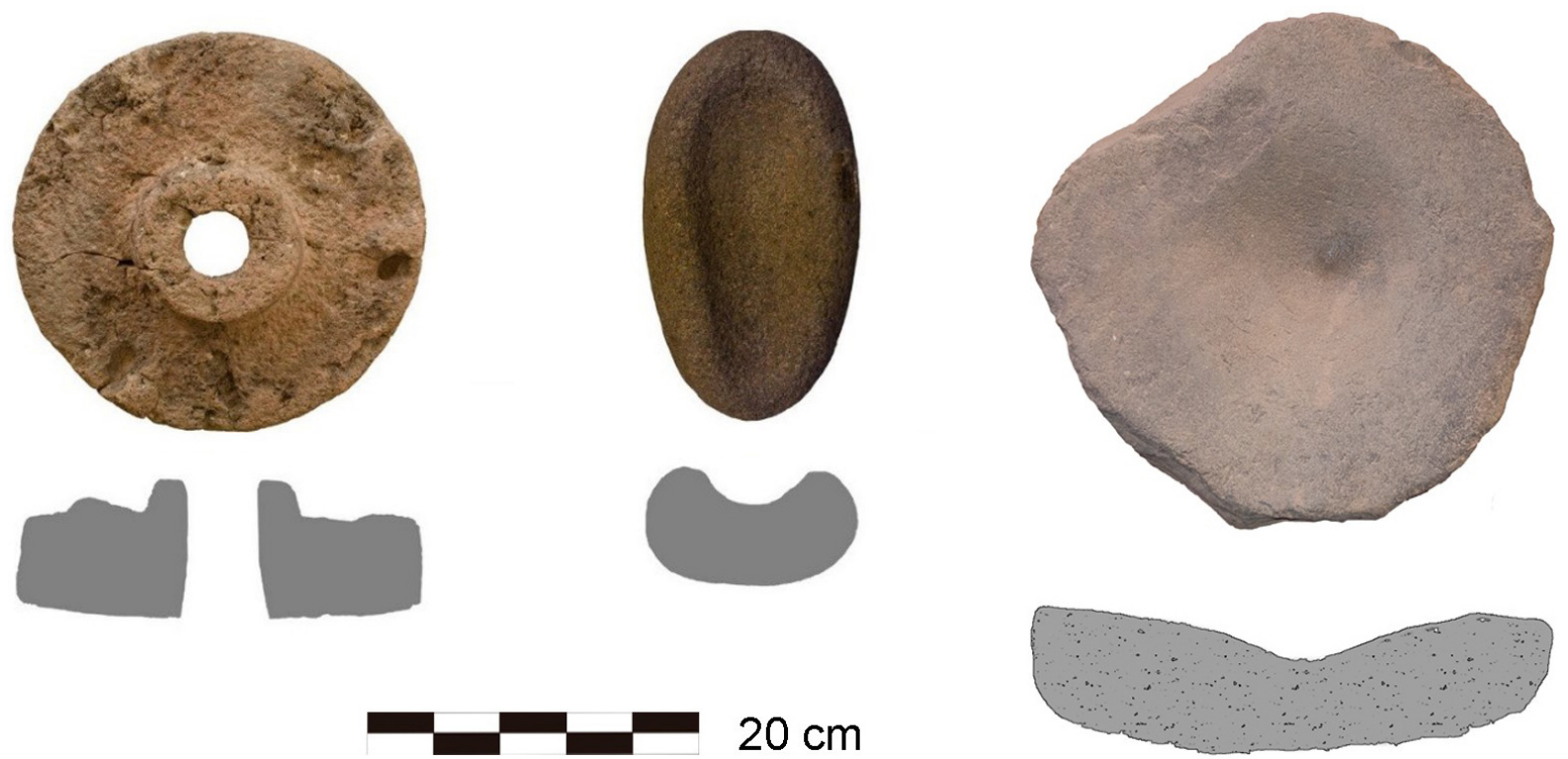

Figure 2. Examples of the types of grinding stones from the Island of Gran Canaria (rotary quern, El PajarArguineguín; “saddle quern”, Cenobio de Valerón-Santa María de Guía; mortar, Cueva Pintada-Gáldar). The scale bar is $30 \mathrm{~cm}$ (6 cm intervals). 
Among the archaeological sites from Gran Canaria studied to date, volcanic tuff is by far the dominant rock exploited for grinding stones and in particular for rotary querns. The only exception is the Cerera Cave (Rodríguez-Rodríguez 2009a), a settlement in the Municipality of Arucas a few kilometres inland from the quarries, where vesicular basalt is the dominant rock type. This difference of raw material suggests a modification of the system of procurement that could be related to the proximity of the extraction sites. However, this notion remains hypothetical pending geochemical analysis of lithic samples from the different sites.

In general, volcanic tuff was the type of rock used almost exclusively to produce rotary querns while other grinding stones including saddle querns and mortars were manufactured mainly with basalt. It is interesting to note that rotary querns continued to be used beyond the Spanish conquest well into the 20th century. Yet these more recent historical mills were hewn from basalt indicating an abandonment of volcanic tuff. It is not until very recently that vesicular basalt rotary quern quarries have been identified on Gran Canaria (see above). This rarity was thought to be rooted in the fact that basalt is harder than tuff rendering it very difficult for the Pre-European Canarians to work with stone tools. Moreover, interviews with the last rotary quern makers and the lack of archaeological evidence contributed to the notion that the basalt querns were fashioned from surface blocks collected in the beds of ravines (Rodríguez-Rodríguez 2010). Current findings, however, point to a different origin.

The three archaeological sites presented in this paper belong to the Cardones geological formation, a pyroclastic volcanic cone rising to a height of $108 \mathrm{~m}$ consisting of a highly vesicular slag with lapilli inclusion ranging between 2 and $6 \mathrm{~cm}$. The semicircular crater opens to the north and, although somewhat altered by anthropic features, is fairly wellpreserved. The dome is inserted in tephritic-phonolitic castings, petrographic features with a glass porphyritic and at times cryptocrystalline matrix (Pérez-Torrado 2000).

The first two sites are basalt quarries located in the Cardones and Cebolla Ravines along the coastline about $700 \mathrm{~m}$ from each other. Circular negatives cut directly into the lava flow reveal the extraction of rotary querns following vertical planes. The position of the quarry faces along the edge of the ravine places the two workings in the "edge quarry" category (Anderson 2014; 2016: 112). The Cardones quarry, a site that is ravaged by a torrent in the rainy season (Figure 3), has a vertical face covering a surface of about $108 \mathrm{~m}^{2}$. The Cebolla quarry face, in turn, covers a slightly larger surface of about $120 \mathrm{~m}^{2}$.

The third site is a quern fashioning workshop (Cave 36) on the left bank of the Cardones Ravine (Figure 4), $600 \mathrm{~m}$ away from the Cardones quarry and $940 \mathrm{~m}$ from the Cebolla quarry. The site presents a series of different layers of occupation. In historical times it served as a stable for livestock. In Pre-European times the stratigraphic sequence shows layers associated with domestic activities, human burials, and a workshop manufacturing rotary querns and other types of grinding implements. The archaeological evidence indicative of a quern workshop consists of abandoned and broken rotary querns and mortars, fashioning debitage and fragments of the stone tools (hammers, malls and picks). The vesicular basalt lithic waste associated with the production totalled more than 14,000 artefacts corresponding to a total weight of $300 \mathrm{~kg}$. Although units 28 and 29 of the quern workshop did not provide organic samples for radiocarbon dating, analyses of two bones found in a stratigraphic unit (SU 32) below the workshop, yielded dates that place the outset of units 28 and 29 between the end of 7th and the end 9th centuries CE (Table 1). So, the estimated life of the workshop spans the 10th to 15th centuries CE with its end coinciding with the Spanish conquest. 


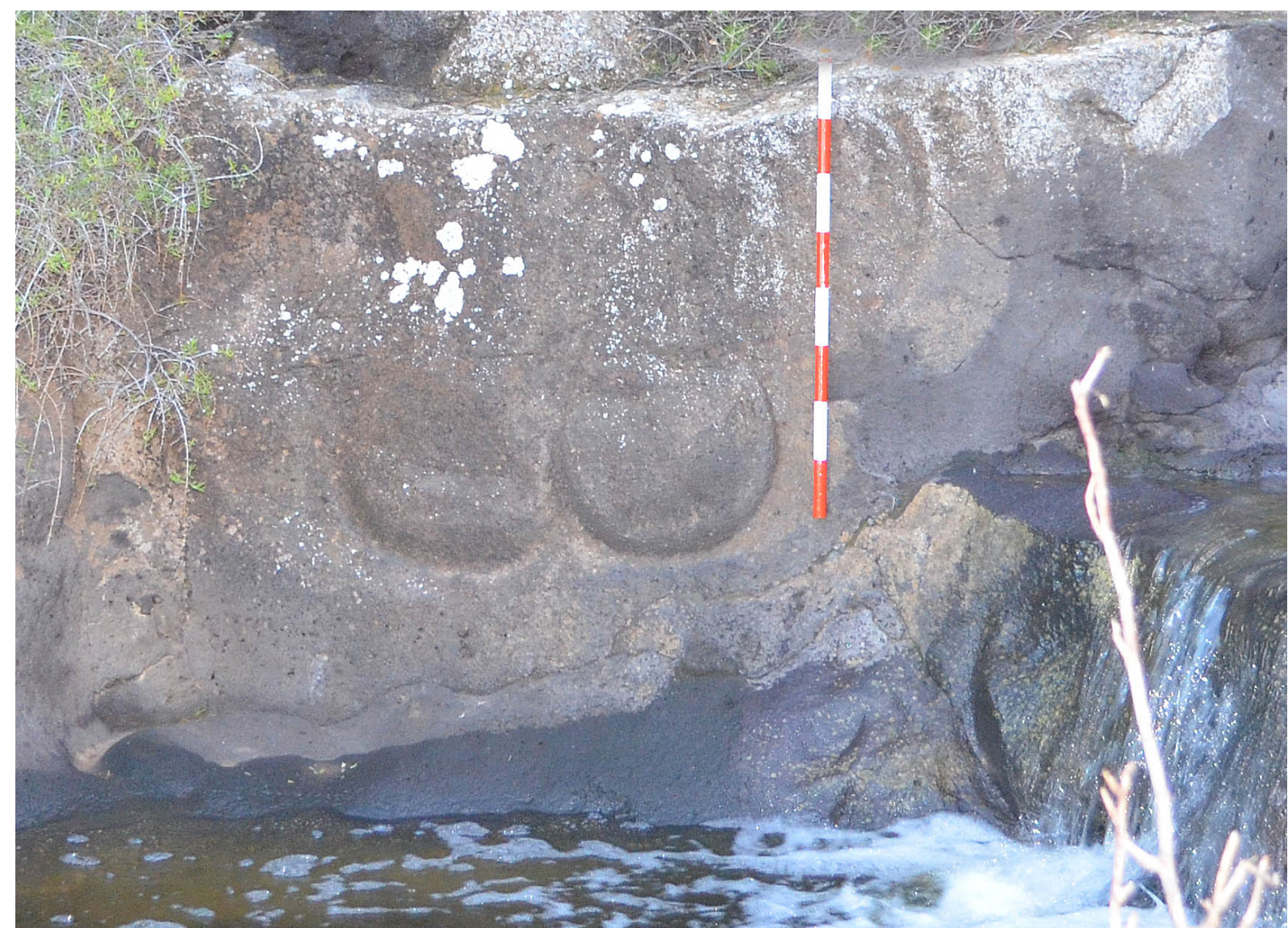

Figure 3. Detail of the basalt quern quarry in the Cardones Ravine (Arucas Municipality) during the rainy season. The quarry face is covered with circular extractions corresponding to negatives of rotary querns measuring less than $40 \mathrm{~cm}$ in diameter.

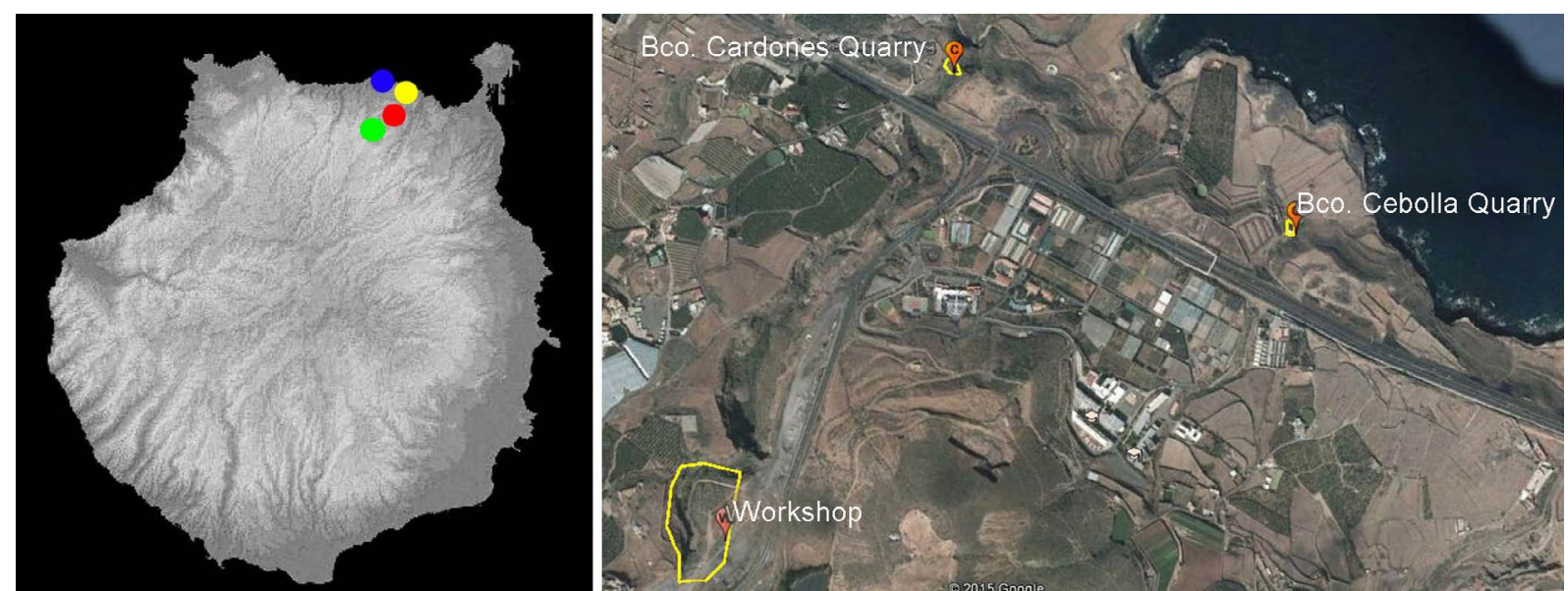

Figure 4. Location of the three quern working sites mentioned in the text. The two along the coast (blue and yellow) are quarries (Cantera Bco Cardones and Cantera de Bco Cebolla). The third is a settlement (red) with a quern workshop. The fourth point (green) marks the Cerera Cave, an inland settlement with the largest known proportion of vesicular basalt querns in the current archaeological record. (Right image from Google Earth). [Download a KML file with the location of the Cantera Bco Cardones and Cantera de Bco Cebolla quarries for viewing in Google Earth and similar software.] 
Table 1. Radiocarbon datings of two bones from a layer below the Cardones Ravine quern workshop. Abbreviations: SU - stratigraphic unit.

\begin{tabular}{lcccc}
\hline Sample no. & SU & Sample & C14 Age BP & Cal 2 o \\
\hline Beta-418621 & 32 & Ovicaprid & $1220 \pm 30$ & 690 to 750 cal. CE (1260 to 1200 cal. BP) and \\
& & bone & BP & 760 to 885 cal. CE (1190 to 1065 cal. BP) \\
Beta-418622 & 32 & Ovicaprid & $1260 \pm 30$ & 670 to $775 \mathrm{cal}$. CE (1280 to 1175 cal. BP) and \\
& & bone & BP & 790 to 800 cal. CE (1160 to 1150 cal. BP) \\
\hline
\end{tabular}

This study was carried out in the line of previous research on volcanic tuff quern quarries (Rodríguez-Rodríguez \& Barroso 2001; Mangas et al. 2006; Rodríguez-Rodríguez et al. 2006a; 2006b; 2010; Rodríguez-Rodríguez 2010). The technological analysis of the grinding stones was carried out following the methodological procedures established by Alonso (1999: 233-236; 2014; 2015), Dubreuil (2004), Adams et al. (2009) and Bofill (2014: 447). The analysis of the extraction and fashioning techniques in quarries also implied undertaking morpho-technical analyses of the tools, notably the stone picks, specifically adapted to work coarse and hard volcanic rock (Galván et al. 1987; Galván \& Hernández 1996; RodríguezRodríguez 1993a; 1993b; 1998; 2009a; 2009b; Rodríguez-Rodríguez \& Francisco Ortega 2012; Naranjo 2013: 54; Naranjo Mayor \& Rodríguez-Rodríguez 2015). The stone picks take on the form of isosceles triangles with two active points that could be either beveled or trihedral (Figure 5). Since the tips were constantly suffered breaks, the tool was designed from the start in a manner to facilitate its maintenance and repair. The extraction marks on the quarry face suggest that these picks served equally to detach the roughouts from the bedrock using the long edge between the two points as a sort of wedge. The multi-functionality of these picks is also seen as they also served as abraders to regularise the surface of the quarry face between extractions and in the subsequent phase of fashioning served to give shape to the querns.

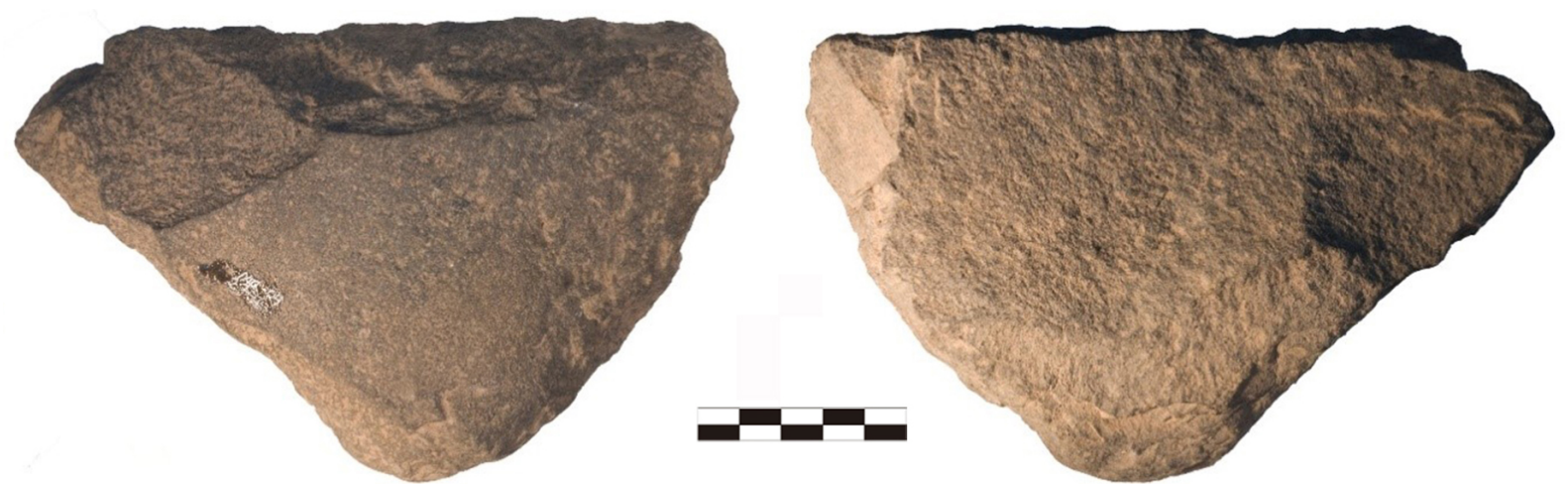

Figure 5. Views of a stone pick serving to extract rotary querns from the quarry of Montaña Quemada, Las Palmas de Gran Canaria. The scale bar is $5 \mathrm{~cm}$ ( $1 \mathrm{~cm}$ intervals).

The study of the workshop finds also consisted of recording the types of marks corresponding to the different production stages of the rotary querns themselves as well as the marks on the quern fashioning tools. In addition, a recent experimental program has led to contrasting the new and old tool marks on both the quarry faces and on the querns. The results obtained in the experimental work, including unintentional accidents among the cylindrical roughouts and picks, were similar to those observed in volcanic tuff quarries.

The quarry face was worked by both direct and indirect percussion with dihedral-beveled tools. Continuous groups of pecking marks are observed on some roughouts indicating that the lapilli roughout was reduced or knapped by the removal of flakes and chips. This was followed by the smoothing of the quern's surface with abrasive, irregular stones or small 
blocks. Another critical task in the final stage of quern making was cutting the eye, a step that could result in an accident. Some broken roughouts reveal that the eye was cut before concluding the shaping of the quern so as to avoid working in vain in the case of an accident. Recent experimentation with volcanic tuff (lapilli) obtained positive results for cutting the eye by combining pecking (direct percussion) and, rubbing (friction) with the same pick.

Units 20, 28 and 29 of the workshop in Cave 36 brought to light 3,734 knapped objects. Morpho-technical analyses were carried out on 1136 artefacts measuring more than $2 \mathrm{~cm}$. The others, smaller than $2 \mathrm{~cm}$, were considered debris and only counted and weighed. Among the artefacts were 14 broken querns and 14,020 flakes and fragments of vesicular basalt measuring more than $1.5 \mathrm{~cm}$. Vesicular basalt debris inferior to $1.5 \mathrm{~cm}$ was only weighed $(110 \mathrm{~kg})$. A series of artefacts associated with different steps of the operational sequence were identified from the lot of larger flakes. Refitting (i.e. mounting like a puzzle) of certain fragments was essential to understanding the process of making and repairing rotary querns, picks and hammers (Cuartero 2014: 88) (Table 2).

Table 2. Quantification of the types of artefacts collected in the rotary quern workshop.

\begin{tabular}{lccc}
\hline $\begin{array}{l}\text { Types of } \\
\text { artefacts }\end{array}$ & $\begin{array}{c}\text { Knapping tools, by- } \\
\text { products and accidents }\end{array}$ & $\begin{array}{c}\text { Rotary quern } \\
\text { fragments }\end{array}$ & $\begin{array}{c}\text { Manufacturing debris (flakes, } \\
\text { fragments and other waste) }\end{array}$ \\
\hline Quantity & 3,734 & 11 & 14,020 \\
Weight & $14,627 \mathrm{~g}$ & $16,329 \mathrm{~g}$ & $296,912 \mathrm{~g}$ \\
\hline
\end{tabular}

\section{Results}

\subsection{Quarries}

The archaeological surveys of these newly discovered basalt quarries reveal that the extraction procedures were very similar to those observed in the volcanic tuff workings (Rodríguez-Rodríguez et al. 2006a). The process began with the regularisation of the outcrop's face by pecking it with a stone pick. This was followed by outlining and carving the trench around the roughout (average diameter: $39.1 \mathrm{~cm}$ ) with the same type of pick. The step of carving the circular trench is carried by both direct and indirect percussion. Splitting the cylinder from the quarry face was also carried out with the same picks serving as wedges. Broken roughouts are common finds in volcanic tuff quarries. They are, by contrast, absent in basalt workings in spite of the fact that basalt is a harder rock. This absence could be explained by the basalt's mechanical property that permits splitting along better defined planes contrary to that of the less homogenous and compact tuff (Figure 6).

\subsection{Workshop: The Cardones workshop}

\subsubsection{Quern fashioning tools}

A wide variety of stone flakes were found in the Cardones workshop that can be classified (Table 3) according to the results of the study of the debitage of the tuff quern quarries (Rodríguez-Rodríguez \& Francisco Ortega 2012). Although no pick was among the debris collected in the workshop, the morphology of the tool can be inferred from a series of resharpening flakes and accidents.

The pick's edges were affected both by the impacts of percussion and the abrasiveness of the rock it worked. These tools therefore required frequent maintenance following different strategies. The tips could at times serve as striking platforms for the removal of symmetrical and asymmetrical crested flakes bearing very rounded ridges. At other times the tips were reworked from the pick's flanks adjacent to the active edges resulting in crested and uncrested flakes with highly rounded ridges. Reworking the pick often resulted a considerable change of 
its original morphology which implies that picks sometimes were partially or totally reconfigured.
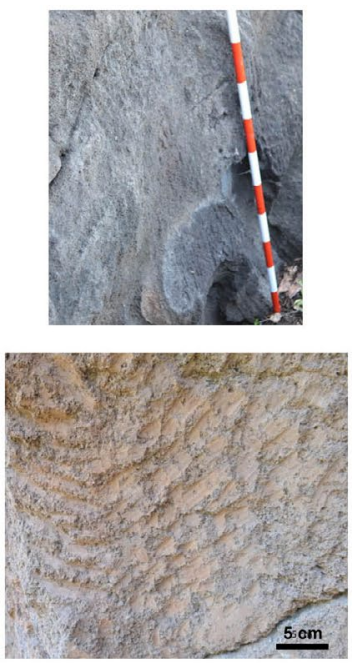

Figure 6. Juxtaposition of the extraction marks of the different stages of the operational sequence of basalt and tuff quern quarries.

Table 3. Classification of flakes from the different stratigraphic units (SU) of the Cardones quern workshop.

\begin{tabular}{lcccccccc}
\hline & SU 20 & \% & SU 28 & \% & SU 29 & \% & Total & \% \\
\hline Unidirectional flakes & 10 & 13.6 & 42 & 12.9 & 125 & 16.9 & 177 & 15.6 \\
Multidirectional flakes & 6 & 8.2 & 26 & 8.1 & 66 & 8.9 & 98 & 8.6 \\
Backed flakes & 1 & 1.37 & 18 & 5.5 & 56 & 7.6 & 75 & 6.6 \\
Resharpening flakes (central crest) & 2 & 2.7 & 2 & 0.6 & 9 & 1.2 & 13 & 1.1 \\
Resharpening flakes (side crest) & 1 & 1.3 & 2 & 0.6 & 18 & 2.4 & 21 & 1.8 \\
Resharpening flakes (no crest) & 1 & 1.3 & 1 & 0.3 & 11 & 1.5 & 13 & 1.1 \\
Cortical flakes & 2 & 2.7 & 6 & 1.8 & 18 & 2.4 & 26 & 2.3 \\
Undetermined flakes & 50 & 68.5 & 227 & 70.1 & 436 & 58.9 & 713 & 62.7 \\
\hline
\end{tabular}

This task is indicated by the presence of backed, unidirectional and, more often, multidirectional flakes with narrow bases. There are also pyramidal shaped fragments resulting from the accidental breakage of the tip. Another indication that picks were only reworked in the workshop is the rarity of cortical flakes. Finally, the majority of the flakes are in fact fragmented and classified as undetermined (Figure 7). Unidirectional flakes (33.9 x $29.3 \times 7.0+16.2 \times 12.7 \times 4.2 \mathrm{~mm}$ ) are characterised by flat butts (59.1\%) followed by faceted (16.48\%) or linear $(13.30 \%)$ butts. $59.2 \%$ of this category show for the most part butts with rounded arrises. Multidirectional flakes (36.6 x 37.6 × $9.3+16.2$ × 16.4 × $7.5 \mathrm{~mm}$ ) also show flat butts (56.7\%) followed by faceted (17.5\%) and linear (8.2\%) butts. Use-wear is visible on $62.0 \%$ of the artefacts. Backed flakes (41.6 x $38.9 \times 11.3+18.1 \times 17.9 \times 10.8 \mathrm{~mm})$ are longer and wider than the others. They have flat butts (65.3\%) followed, interestingly, by faceted $(9.3 \%)$ and dihedral $(12.0 \%)$ butts. They also show a very high rate of use-wear, mainly on the rounded arrises (73.0\%). Flakes from resharpening the active tip (31.9 x 27.1 x $9.5+11.7$ x 15.3 x $3.9 \mathrm{~mm}$ ) are the most singular from the morphological and technological points of view. It is the only case where the main butts are faceted $(41.7 \%)$ followed in second place by flat butts (37.5\%) and in third place by punctiform butts (20.8\%). Every example of this type reveals use-wear. The few characteristic cortical and undetermined flakes are not described since, as noted previously, as they are mainly broken blanks. 

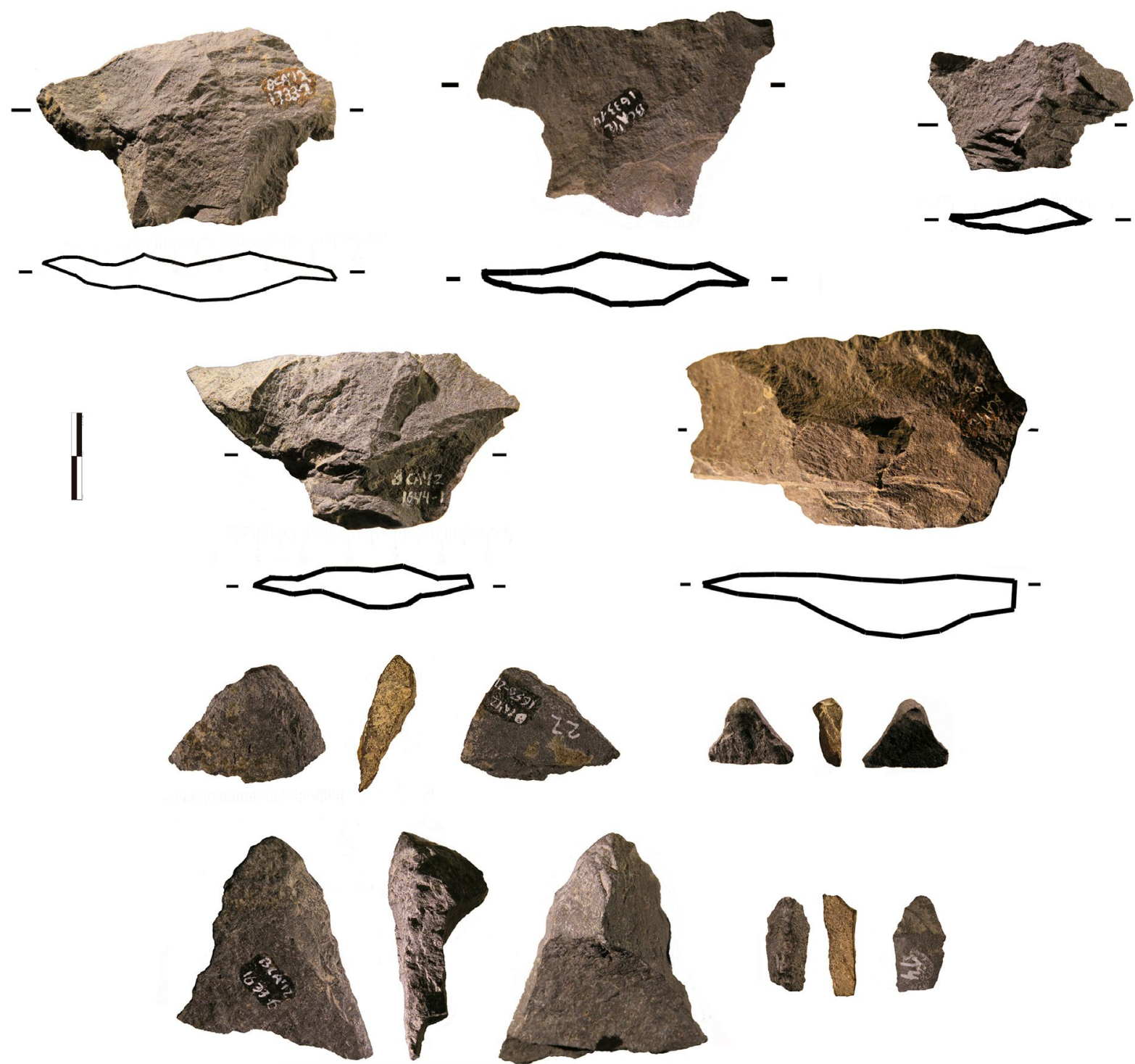

Figure 7. Working debris of the Cardones workshop: a) flakes with narrow bases and b) resharpening flakes of the tip of the picks. The scale bar is $2 \mathrm{~cm}$ long ( $1 \mathrm{~cm}$ sections).

\subsubsection{Grinding stones}

The Cardones workshop is the first site that offers a wide view of a variety of types of querns associated with a broad range of types of working debris. The artefacts, for the most part associated with fashioning and finishing of grinding stones, are classified in different categories: grinding stones, abraders-polishers, upper stones (manos, i.e. upper stones used with a to-and-from movement), hammers and other multifunctional tools (Table 4). At this stage the artefacts have been quantified according to their length and total weight as specified in Table 5.

The working debris superior to $5 \mathrm{~cm}$ in length (1680 pieces) was retained for the study. Debitage inferior to $5 \mathrm{~cm}$, in turn, was considered uncharacteristic. The technological analysis of the larger pieces was not simple due to the physical properties (granularity, coarseness, size of the vacuoles) of the vesicular basalt. Furthermore, the knapping marks, carving or pecking of quern roughouts were often erased or rubbed out by subsequent abrasive work. However, after long observation of the debitage, we began to identify pieces that could be defined as flakes. A flake is described following the definition advanced by Cotterell \& Kamminga 
(1987) as any fragment detached from a nucleus. A flake therefore does not necessarily have to be limited to the type with conchoidal fractures.

Table 4. Grinding stones and the tools to make them collected in different stratigraphic units (SU) at the Cardones workshop.

\begin{tabular}{|c|c|c|c|c|c|c|c|c|c|}
\hline & SU 28 & $\%$ & SU 29 & $\%$ & SU 34 & $\%$ & Total & $\%$ & Weight \\
\hline \multicolumn{10}{|l|}{ Grinding stones } \\
\hline Rotary querns & 2 & 18.1 & 4 & 36.4 & 5 & 45.5 & 11 & 100 & $16,389 \mathrm{~g}$ \\
\hline Mortar & & & & & 1 & 100 & 1 & 100 & $4,365 \mathrm{~g}$ \\
\hline Upper stones (manos) & & & 1 & 50 & 1 & 50 & 2 & 100 & $757 \mathrm{~g}$ \\
\hline \multicolumn{10}{|c|}{ Tools to manufacture the grinding stones } \\
\hline Polishers and abraders & 1 & 25 & 3 & 75 & & & 4 & 100 & $1,557 \mathrm{~g}$ \\
\hline Hammers & & & 18 & 100 & & & 18 & 100 & $3,628 \mathrm{~g}$ \\
\hline Multi-functional tools & 1 & 12.5 & 3 & 37.5 & 4 & 50 & 8 & 100 & $6,066 \mathrm{~g}$ \\
\hline
\end{tabular}

Table 5. Classification by length and total weight of the working debris from the manufacture of grinding stones.

\begin{tabular}{lccccc}
\hline & $<\mathbf{1 ~ c m}$ & $\mathbf{1 - 1 . 5} \mathbf{~ c m}$ & $\mathbf{1 . 5 - 3} \mathbf{~ c m}$ & $\mathbf{3 - 5} \mathbf{~ c m}$ & $>\mathbf{5 ~ c m}$ \\
\hline Quantity & - & - & 6127 & 6213 & 1680 \\
Weight & $65,238 \mathrm{~g}$ & $44,173 \mathrm{~g}$ & $22,906 \mathrm{~g}$ & $60,007 \mathrm{~g}$ & $110,654 \mathrm{~g}$ \\
\hline
\end{tabular}

Flakes detached from rotary quern roughouts are therefore characterised by narrow and usually flat or linear butts or by their lower convex face which becomes more regular towards the butt. Their lower surfaces do not exhibit the characteristic bulb, ripples and hackles due to the rock's coarseness (Inizan et al. 1999: 34; González \& Ibáñez 1994; Clemente et al. 2015). The point of impact is characterised by a white abraded surface that contrasts with the darker colour of the rock. The distal areas of the flakes are less regular and often bear fractured, hinged or stepped ends. These features indicate that many of the flakes are broken. Although the dorsal surface is very irregular, arrises and negatives from previous flakings can be observed. Reconstruction of the steps in the shaping of rotary quern preforms is seen by the refitting of the fragments of certain artefacts (Figure 8).
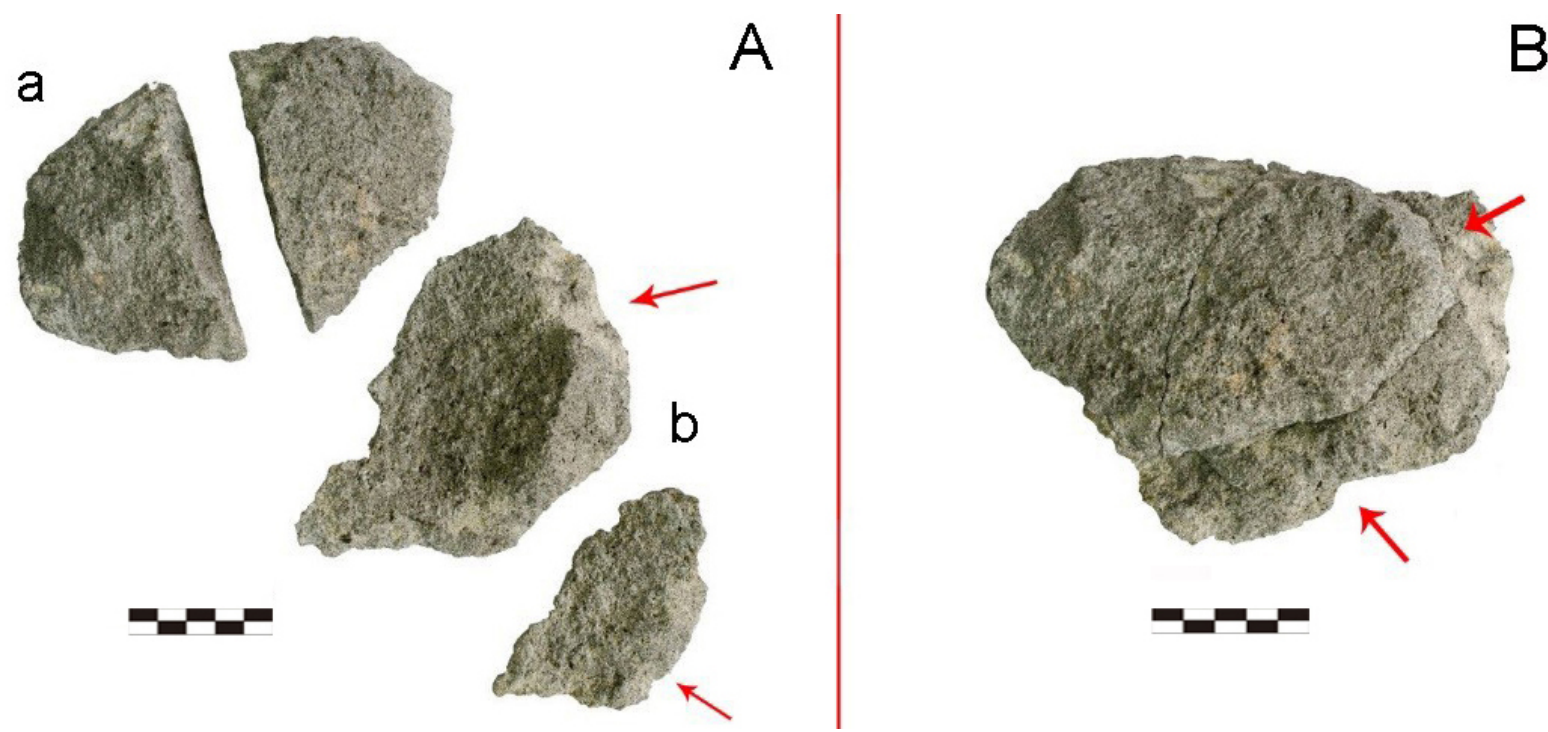

Figure 8. Example of the refitting of vesicular basalt flakes from the fashioning of a rotary quern at the Cardones workshop. A) Fragment: Assemblage of flakes (a. Siret accidental break b. unidirectional flakes), B) result of flakes refitted. The scale bar is $5 \mathrm{~cm}$ long ( $1 \mathrm{~cm}$ intervals). 
The manufacture of querns in the workshop can be broken down into four main stages. The quern maker in the first phase reduced the size of the cylindrical preform by direct percussion with massive basalt hammers. The hardness of vesicular basalt and the need to apply sharp strikes resulted in the fracture of some hammers as seen by abandoned examples bearing multiple impacts (Figure 9). Most of the flakes that we have analysed in this study belong to this initial phase. As seen in the orientation of the refitted flakes, work began on the perimeter of the preform. The second phase consisted of regularising its surface. This was carried out by pecking with hammers (direct or indirect percussion) or with dihedral beveled tipped tools such as picks. The elongated marks on some flakes and quern fragments reveal the shape of the active edges of these tools (Figure 10). The first and second phases were carried out alternatively as evidenced by big flakes with dorsal surfaces covered completely with this type of mark. The second phase is characterised by the use of direct percussion resulting in most of the debris inferior to $5 \mathrm{~cm}$.

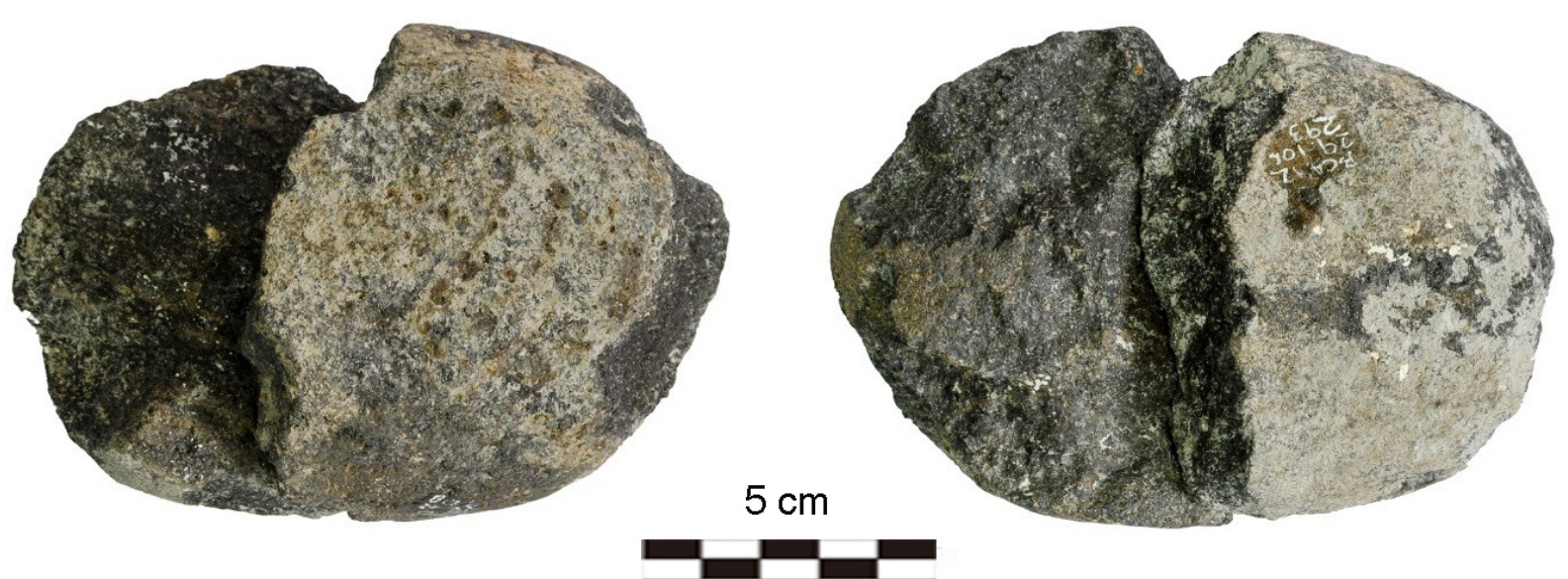

Figure 9. Hammer for reducing the rotary quern cylindrical blank. Cave 36, Cardones workshop. The scale bar is $5 \mathrm{~cm}$ (1 cm intervals).
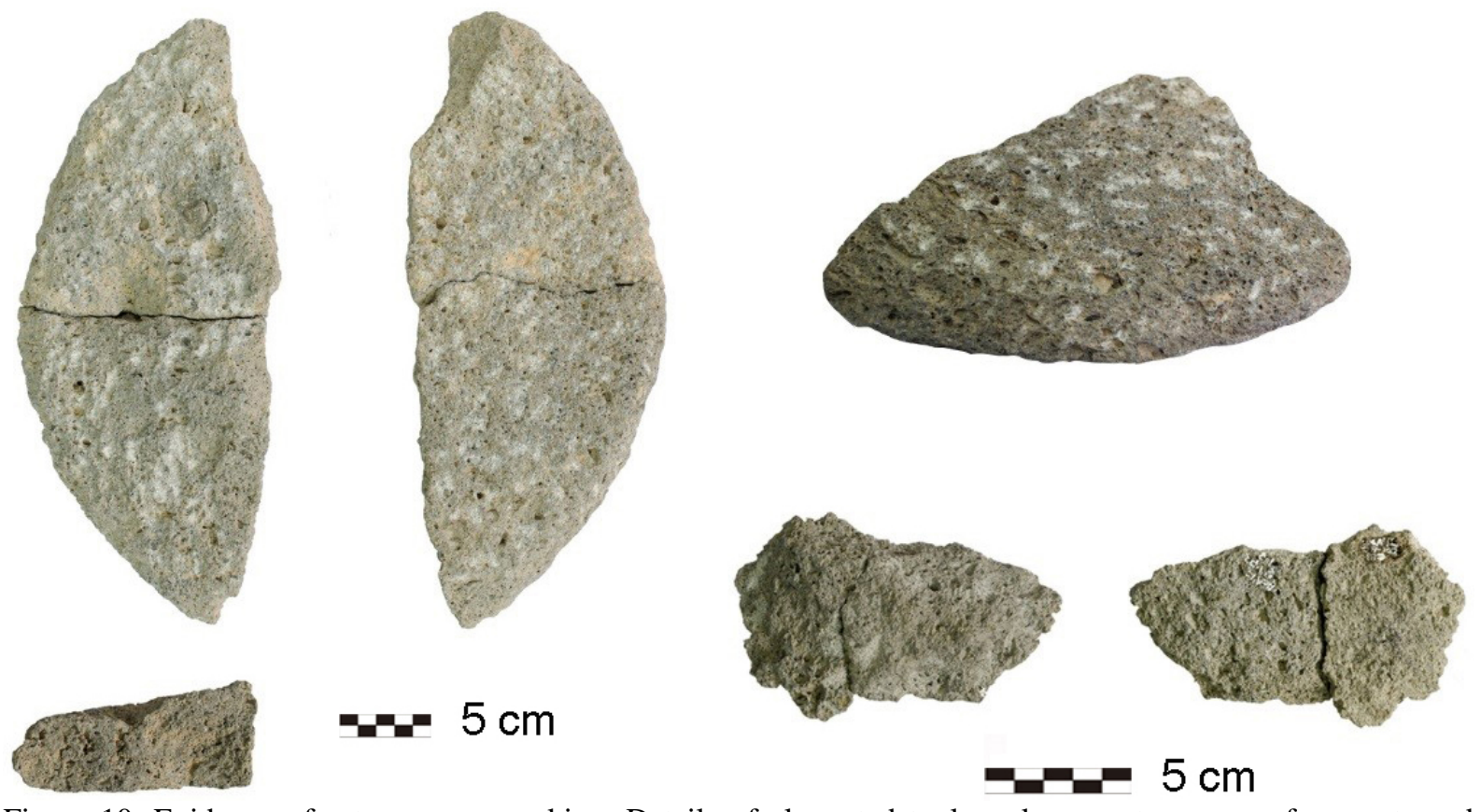

Figure 10. Evidence of rotary quern pecking. Details of elongated tool marks on rotary quern fragments and working flakes. The scale bar is $5 \mathrm{~cm}$ (1 cm intervals). 
The cutting of the quern's eye was the third phase after the roughout attained its final cylindrical form. As noted previously, this was a critical moment in the sequence as seen by some broken querns found in the workshop. It is not clear if the eye was cut by direct or indirect percussion. We tend to lean towards the second option as the indirect percussion technique allowed the quern maker to maintain a higher measure of control over the amount of force and the accuracy of the impacts. This technique was probably also combined with abrasive actions.

The fourth and final phase involved the smoothing of the rotary quern surfaces, actions that leave microscopic striations that can be analysed by binocular microscope. The abrading tools included irregular fragments of vesicular basalt as well as recycled fragments of broken rotary querns (Figure 11). These types of polishers were operated by a reciprocating, to-andfor, motion that produced characteristic centimetric "channels" on their surfaces. The larger channels on certain pieces (Figure 11) appear to have served to work the edges of the rotary querns as they are very often equivalent in form to that part of the quern.
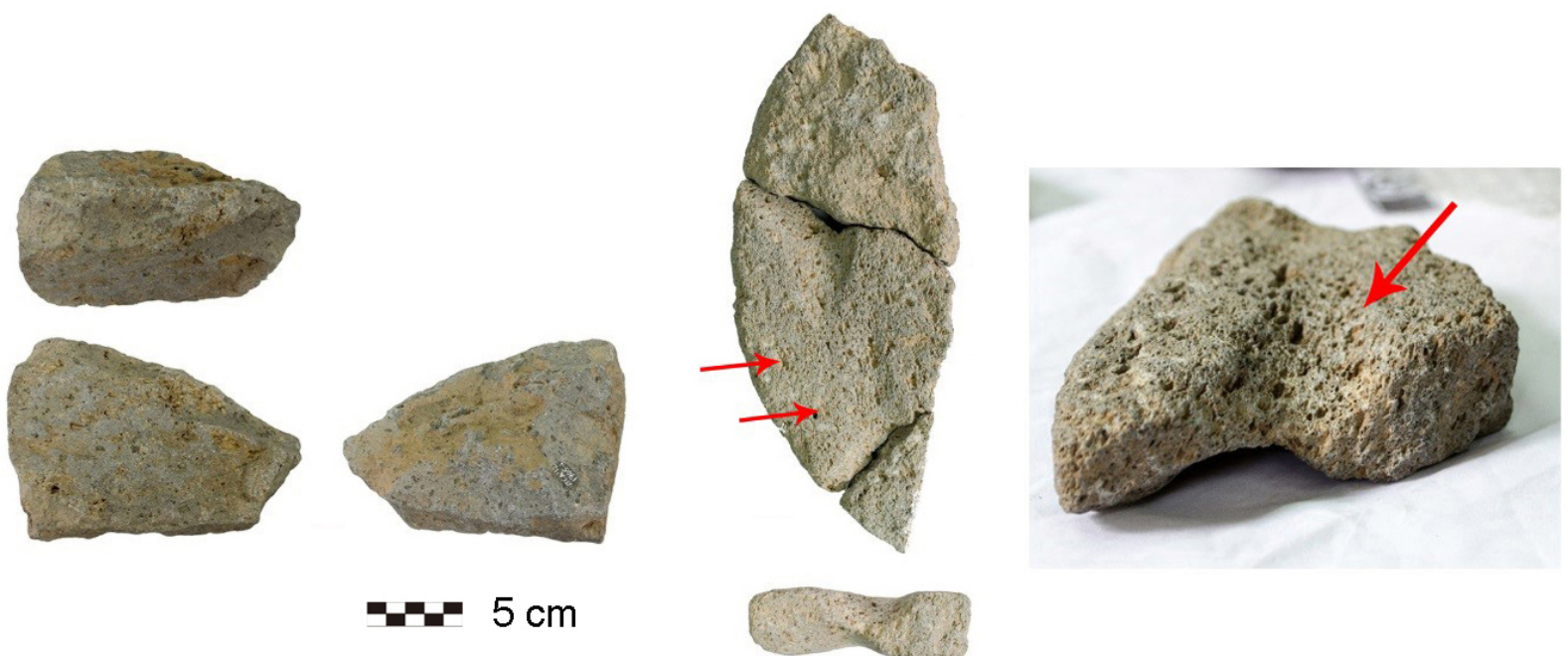

Figure 11. Irregular cobble used as an abrader (left); broken rotary quern fragments with channels indicating they served as abraders (centre); detail of a large channel indicating the rock served to regularise the edges of a rotary quern (right). The scale bar is $5 \mathrm{~cm}$ (1 cm intervals).

\section{Discussion and conclusions}

The study of the Barranco Cardones and Barranco Cebolla quarries and the quern workshop (Cave 36) has led to the reconstruction of the operational sequence of vesicular basalt rotary quern production. It has also resulted in a general improvement of the knowledge of grinding stone assemblages in settlements and linked previous tuff quarry research (Rodríguez - Rodríguez \& Barroso 2001; Mangas et al. 2006; 2008; Rodríguez- Rodríguez et al. 2006a; 2006b; 2010; Rodríguez - Rodríguez 2010: 28) with an experimental program conducted in 2014. The testing of hypotheses has helped clarify questions regarding extraction techniques and the process of manufacture of tuff querns. The study of the Barranco Cardones sites has also shown that the production process of vesicular basalt querns was very similar to that of lapilli models, in spite of the great difference of fracture mechanisms between the two types of rocks.

The research has also identified the different procedures carried out in the quarries. This part of the analysis focused on "reading" the tool marks on both the basalt and tuff quarry faces. Although the production centres shared a similar operational sequence, the lack of abandoned roughouts at the basalt workings suggests that this rock was better suited to be detached or split from bedrock. Yet, the greater number of tuff quarries compared to basalt 
quarries, combined with the greater proportion of tuff rotary querns in settlements, suggests that vesicular basalt extraction was more arduous and time consuming and hence less frequent. Moreover, the atypical high proportion of basalt rotary querns at the settlement of Cerera can be explained by its proximity to the two basalt quarries and workshop.

The absence of picks or broken querns at the foot of the basalt quarries can be explained in part by the occasional torrent and in part by the presence of a nearby rotary quern workshop serving to fashion the rough cylinders. The study of the workshop is, in fact, the highlight of the current research. Among the workshop artefacts are percussion tools for flaking, hammers for pecking and abraders for polishing. The debitage shows the same type of waste as that observed at the volcanic tuff quarries. Despite the absence of picks, certain types of debitage points to the reworking and rejuvenation of the active edges of the picks of the type that are characteristic of quarry contexts (Rodríguez-Rodríguez \& Francisco Ortega 2012). These features therefore confirm the standardisation of basalt picks for quern fashioning. Furthermore, this type of use is observed by their presence in grinding stone production contexts as well as in other settings such as carving tuff for architectural features.

The analysis of the stone working debitage and the abandoned tool fragments offer new data suggesting recurrent production strategies and standardisation of the different tools in different production contexts, elements that reflect the skill of the quern makers. The new data also corroborates that a hard raw material such as vesicular basalt can be worked without iron tools. It is particularly interesting that fragments of broken rotary querns served as abraders to polish and regularise the surface of other querns.

The evidence collected in this research suggests the presence of skilled and experienced specialists. Although it is difficult to gauge the access of the rest of the population to production centres, and how the centres regulated their products, provenance studies currently in process should be able to specify the distribution patterns of querns and compare them with the spread of other abiotic artefacts such as obsidian. In any case, the data obtained in the two new quern quarries and in the workshop provides further evidence of the complexity of the social relations of production on the Island of Gran Canaria in Pre-Hispanic times.

\section{Acknowledgements}

This work has been carried out in the framework of the research project HAR 201341934. Yurena Naranjo is a beneficiary of a FPI grant from the Ministerio de Economía y Competitividad. The authors also recognise the collaboration of Arqueocanarias S. L.

\section{References}

Adams, J.L., Delgado, S., Dubreuil, L., Hamon, C., Plisson, H., \& Rish, R. 2009, Functional analysis of macro-lithic artefacts: A focus on working surfaces. In: Non-flint Raw Material Use in Prehistory. Old Prejudices and New Direction. $15^{\text {th }}$ UISPP Congress, Session C77, Lisbon, September 2006 (Sternke, F., Eigeland, L., \& Costa, L. J., Eds.), BAR International Series Vol. 1939, Archaeopress, Oxford: p. 43-66.

Alonso, N. 1999, De la llavor a la farina. Els processos agrícoles protohistòrics a la Catalunya occidental. Monographies d’Archéologie Mediterranéenne (MAM) Vol. 4. Publication de l'UMR 154 du Centre national de la recherche scientifique, Lattes, 328 p. (in Catalan) ("From seed to flour: The protohistoric agricultural processes in western Catalonia”) 
Alonso, N. 2014, Etnoarqueología del proceso de molienda manual de cereales: Grañones, sémolas y harinas. Revista d'Arqueologia de Ponent, 24: 113-136. (in Spanish) ("The ethnoarchaeology of cereal grinding: Groats, semolina and flour”). URL: http://www.rap.cat/online/rap24/10_Alonso.pdf

Alonso, N. 2015, Moliendo en íbero, moliendo en griego: Aculturación y resistencia tecnológica en el Mediterráneo occidental durante la Edad del Hierro. Vegueta, 15: 2336. (in Spanish) ("Milling in Iberian, milling in Greek: Acculturation and technological resistance in the Western Mediterranean during the Iron Age”)

URL: http://revistavegueta.ulpgc.es/ojs/index.php/revistavegueta/article/view/294

Anderson, T. J. 2014, Moleras en la Península Ibérica: Una primera clasificación de las canteras de molinos. Revista d'Arqueologia de Ponent, 24: 157-174. (in Spanish) (“A preliminary classification of millstone quarries in the Iberian Peninsula") URL: http://www.rap.cat/online/rap24/12_Anderson.pdf.

Anderson, T. J. 2016, Turning Stone to Bread: A Diachronic Study of Millstone Making in Southern Spain, Southampton Monographs in Archaeology New Series Vol. 5, The Highfield Press, Exeter, 321 p.

Atoche, P. 2013, Consideraciones en relación con la colonización protohistórica de las Islas Canarias. Anuario de Estudios Atlánticos, 59: 521-564. (in Spanish) (“Considerations in relation with the Protohistoric Colonization of the Canary Islands”). URL: http://anuariosatlanticos.casadecolon.com/index.php/aea/article/view/1820

Bofill, M. 2014, Inicio y consolidación de las prácticas agrícolas durante el neolítico en el Levante mediterráneo (septentrional y central): El proceso de molienda y trituración a partir del análisis funcional del instrumental macrolítico. Ph.D thesis, Departament d'Antropologia Social i de Prehistòria, Universitat Autònoma de Barcelona, Barcelona, 377 p. (in Spanish) ("Beginning and consolidation of agricultural practices during the Neolithic period in the Mediterranean (northern and central) Levant: The milling and grinding process from the functional analysis of the macrolithic tools”)

Clemente, I., Lazuén, T., Astruc, L., \& Rodríguez-Rodríguez, A. 2015, Use-wear analysis of nonflint lithic raw materials: The cases of quartz/quartzite and obsidian. In: Use-Wear and Residue Analysis in Archaeology (J.M. Marreiros, J.F. Gibaja Bao \& N. F. Bicho, Eds), Springer, London: p.59-81. doi:10.1007/978-3-319-08257-8_5

Cotterell, B., \& Kamminga, J. 1987, The Formation of Flakes, American Antiquity, 52(4): 675-708. doi:10.2307/281378

Cuartero, F. 2014, Percutores y retocadores: Interpretación de comportamientos técnicos en el Paleolítico Medio peninsular desde el análisis de instrumental del tallador. Ph.D. thesis, Departamento de Prehistoria y Arqueología. Universidad Autónoma de Madrid, Madrid, 409 p. (in Spanish) ("Hammers and retouchers: Interpretation of technical behaviour in the Middle Paleolithic in Iberian Peninsula from the analysis of knapping's instruments”)

Dubreuil, L. 2004, Lons-terms trend in Natufian subsistence: A use-wear analysis of ground stone tools, Journal of Archaeological Science, 31: 1613-1629. doi:10.1016/j.jas.2004.04.003 
Francisco-Ortega, M.I. 2016, Estudio de los procesos de obtención, fabricación y distribución de las industrias líticas talladas prehispánicas de la isla de Gran Canaria. Ph.D. thesis, Departamento de Prehistoria, Antropología e Historia Antigua. Universidad de La Laguna, La Laguna, 314 p. (in Spanish) (“Analysis of the processes of production, manufacture and distribution of prehispanic knapped stone industries of the island of Gran Canaria”)

Galván, B., Rodríguez-Rodríguez, A.C., \& Francisco, M.I. 1987, Propuesta metodológica para el estudio de las industrias líticas talladas de las Islas Canarias, Tabona, 6: 9-90. (in Spanish) ("Methodological proposal for the study of the lithic knapped industries of the Canary Islands")

Galván, B., \& Hernández, C. M. 1996, Aproximación a los Sistemas de captación y transformación de las industrias líticas canarias. Tabona, 9: 45-73. (in Spanish) (“An approach to the systems of catchment and transformation of the lithic industries from the Canary Island”) URL: http://publica.webs.ull.es/upload/REV\%20TABONA/09\%20\%201996/02\%20(Bertila\%20Galv\%C3\%A1n\%20Santos\%20y\%20otro).pdf

González, J.E., \& Ibáñez, J.J. 1994, Metodología de Análisis Funcional de instrumentos tallados en sílex. Cuadernos de Arqueología, 14. Universidad de Deusto, Bilbao, 302 p.(in Spanish) ("Methodology for Functional Analysis of knapped tools in flint”)

Inizan, M.L., Reduron-Ballinger, M., Roche, H., \& Tixier, J. 1999, Technology and terminology of knapped stone. Préhistoire de la Pierre Taillée, Vol. 5 (trans. FéblotAugustins, J. ), Cercle de Recherches et d'Etudes Préhistoriques, Maison de l'Archéologie et de l'Ethnologie, Nanterre, 191 p. URL: http://www.mae.uparis10.fr/prehistoire/IMG/pdf/Technology_and_Terminology_of_Knapped_Stone.pdf

Maca-Meyer, N., Arnay, M, Rando, J.C., Flores, C, González, A.M., Cabrera, V.M., \& Larruga, J.M. 2004, Ancient mtDNA analysis and the origin of the Guanches. European Journal of Human Genetics, 12(2): 155-162. doi:10.1038/sj.ejhg.5201075

Mangas, J., Rodríguez-Rodríguez, A., Francisco, I., \& Martín, E. 2006, Canteras aborígenes de molinos de mano de la isla de Gran Canaria (España): Caracterización petrológica de tobas de lapilli. Geo-Termas, 10: 1301-1304. (in Spanish) ("Quarries of aboriginal millstones in the Gran Canaria Island (Spain): Petrologic characterization of lapilli tuffs”) URL: http://www.webs.ulpgc.es/canatlantico/pdf/19/26/tobas_lapilli.pdf

Morales Mateos, J. 2010, El uso de las plantas en la Prehistoria de Gran Canaria: Alimentación, agricultura y ecología. Monografías Cueva Pintada Vol. 1. Cabildo Insular de Gran Canaria, Las Palmas de Gran Canaria, 243 p. (in Spanish) ("The use of plants in the Prehistory of Gran Canaria: Food, agriculture and ecology”)

Morales, J., Rodríguez-Rodríguez, A., González Marrero, M.C., Martín-Rodríguez, E., Henríquez-Valido, P., \& del Pino-Curbelo, M. 2014, The archaeobotany of long-term crop storage in northwest African communal granaries: A case study from pre-Hispanic Gran Canaria (cal. AD 1000-1500). Vegetation History and Archaeobotany, 23(6): 784804. doi:10.1007/s00334-014-0444-4

Naranjo, Y. (2013), Estudio de los materiales de molienda y otro utillaje pesado en las Islas Canarias en la etapa preeuropea. Un estudio preliminar dedicado a la Gran Canaria preeuropea. Master dissertation, Universidad de Las Palmas de Gran Canaria, Las Palmas de Gran Canaria, 118 p. (in Spanish) (“Analysis of grinding stone tools and other massive tools in Canary Islands in the pre-European stage. A preliminary study about pre-European Gran Canaria Island”) 
Naranjo-Mayor, Y., \& Rodríguez-Rodríguez, A.C. 2015, Artefactos e instrumentos de piedra en un espacio de almacenamiento colectivo. El caso de El Cenobio de Valerón (Gran Canaria, España). Munibe, 66: 291-208. (in Spanish) ("Lithic implements in a communal granary. The example of Cenobio de Valerón (Gran Canaria, Spain)”) doi:10.21630/maa.2015.66.16

Naranjo, Y., \& Rodríguez-Rodríguez, A.C. 2016, Propuesta de clasificación de los instrumentos de molienda y otro utillaje lítico no tallado de los antiguos canarios. Hacia una tipología morfo-funcional. In: XXI Coloquio de Historia Canario-Americano. Las Palmas de Gran Canaria. XXI, Cabildo Insular de Gran Canaria: p.1-11. (in Spanish) ("Proposal for classification of milling and other not knapped stone tools of the ancient Canarians. Towards a typology morpho-functional”)

URL: http://coloquioscanariasamerica.casadecolon.com/index.php/CHCA/article/view/ 9557/

Pérez-Torrado, F.J. (2000), Historia Geológica de Gran Canaria. (unpublished report). I Jornadas Canarias de Geología. Universidad de Las Palmas de Gran Canaria, Las Palmas de Gran Canaria: p. 9-15. (in Spanish) (“Geological History of Gran Canaria”)

Rodríguez-Rodríguez, A. C. 1993a, La industria lítica de la Isla de La Palma. "Cuevas de San Juan": Un modelo de referencia, (microfilm), Ph.D., Departamento de Prehistoria, Antropología e Historia Antigua. Universidad de La Laguna, La Laguna, 459 p. (in Spanish) ("The lithic industry of the Island of La Palma. "Cuevas de San Juan”: A reference model”)

Rodríguez-Rodríguez, A. C. 1993b, Analyse fonctionnelle des outillages lithiques en basalte de l'île de La Palma (Îles Canaries). Prémiers résultats. In: Traces et fonction. Les Gestes Retrouvés, Vol. 2 (Anderson, P.C., Beyries, Otte, M., Plisson, H., Eds.), Études et recherches archéologiqyes de l’ Université de Liége, Vol. 50, Liège: p. 295-301. (in French) ("Functional analysis of the basalt stone tools of the island of La Palma (Canary Islands). First results”)

Rodríguez-Rodríguez, A. C. 1998, Primeras experiencias de análisis funcional en los instrumentos de basalto tallado de Canarias. El ejemplo del material prehistórico de la isla de La Palma. Vegueta, 3: 29-46. (in Spanish) ("First approach of functional analysis in the knapped basalt tools of the Canary Islands. The example of the prehistoric material of the island of La Palma”)

URL: http://revistavegueta.ulpgc.es/ojs/index.php/revistavegueta/article/view/143/289

Rodríguez-Rodríguez, A. C. 2009a, La gestión de los recursos líticos en el yacimiento de La Cerera. In: El yacimiento arqueológico de La Cerera: Un modelo de ocupación en la isla de Gran Canaria (González Quintero, P. \& Moreno, M., Eds.), Cuadernos de Patrimonio Vol. 9. Ediciones del Cabildo de Gran Canaria, Las Palmas de Gran Canaria: p. 205-276. (in Spanish) ("Lithic resources management at the site of La Cerera”)

Rodríguez-Rodríguez, A. C. 2009b, Use-wear analysis on volcanic grainy rocks: Problems and perspectives. The example of Canary Island material. In: Recent Functional Studies on non-flint stone tools: Methodological improvements and Archaeological Inferences (de Araújo Igreja, M. \& Clemente-Conte, I., Eds.), Lisboa: p. 1-10. 
Rodríguez-Rodríguez, A. C. 2010, Piedra a piedra: La explotación de minas y canteras en la Gran Canaria preeuropea. In: La cultura de la piedra. VII Jornadas de patrimonio Cultural de Teror (Suárez, V., Trujillo, G.A. \& Domínguez, O., Eds.), Anroart Ediciones, Las Palmas de Gran Canaria: p. 18-41. (in Spanish) ("Stone by stone: Mining and quarrying in pre-European Gran Canaria”)

Rodríguez-Rodríguez, A. C. \& Barroso, V. 2001, Labrar la piedra para moler el grano. La explotación prehistórica de las canteras de molinos de toba en la isla de Gran Canaria. El Pajar, 10: 4-9. (in Spanish) ("Carving stone for grinding the grain. Prehistoric tuff millstone quarrying on the island of Gran Canaria”)

Rodríguez-Rodríguez, A.C. \& Francisco Ortega, M.I. 2012, Estudio de los picos tallados de la época preeuropea de Gran Canaria. Un ejemplo de especialización en el trabajo a partir de las evidencias recuperadas en la cantera de molinos de Montaña Quemada. Complutum, 23(1): 77-97. (in Spanish) (“The Precolonial knapped picks of Gran Canaria (Canary Islands). A case study of craft specialization at the stone grinders quarry of Montaña Quemada”) doi:10.5209/rev_cmpl.2012.v23.n1.39532

Rodríguez-Rodríguez, A.C., Mangas Viñuela, J., Buxeda i Garrigós, J, Martín Rodríguez, E., \& Francisco Ortega, M.I. 2010, La explotación de las canteras de molinos de mano rotatorios en la Gran Canaria preeuropea. In: Minerales y rocas en las sociedades de la prehistoria (Domínguez-Bella, S., Ramos Muñoz, J., Gutiérrez López, J.M. \& Pérez Rodríguez, M., Eds), Grupo de Investigación HUM-440, Universidad de Cádiz, Puerto Real, Cádiz: p. 371-380. (in Spanish) ("The exploitation of the quarries of rotary querns in the pre-European period in Gran Canaria Island”)

Rodríguez-Rodríguez, A. C., Martín, E., Mangas Viñuela, J., \&. Francisco Ortega, M.I. 2006a, Las canteras de molinos de mano de Gran Canaria. Anatomía de unos centros de producción singulares. Tabona, 15: 115-41. (in Spanish) ("The hand rotary querns quarries from Gran Canaria Island. Anatomy of special production centers”) URL: http://publica.webs.ull.es/upload/REV\%20TABONA/15\%20\%202006/07\%20(Amelia\%20Rodr\%C3\%ADguez\%20Rodr\%C3\%ADguez,\%20Ernesto \%20Mart\%C3\%ADn\%20Rodr\%C3\%ADguez\%20y\%20otros).pdf

Rodríguez-Rodríguez, A.C., Martín Rodríguez, E., Mangas Viñuela, J., del Cristo González Marrero, M., \& Buxeda i Garigos, J. 2006b, La explotación de los recursos líticos en la isla de Gran Canaria. Hacia la reconstrucción de las relaciones sociales de producción en época preeuropea y colonial. In: Sociedades prehistóricas, recursos abióticos y territorio (Martínez, G., Morgado, A., \& Afonso, J., Eds.), Fundación Ibn-Jatib de Estudios de Cooperación Cultural, Granada: p. 367-391. (in Spanish) (“The exploitation of lithic resources on the island of Gran Canaria. Towards the reconstruction of social relations of production in pre-European and colonial stages”)

Rodríguez-Rodríguez, A.C., Morales Mateos, J., Pino Curbelo, M. del., Naranjo Mayor, Y., Martín Rodríguez, E., \& González Marrero, M. C. 2012, Espacios de producción especializada, excedentes y estratificación social en la Gran Canaria pre-europea. Tabona, 19: 101-23. (in Spanish) (“Specialized production centers, surplus and social stratification in pre-European Gran Canaria Island”)

URL: http://publica.webs.ull.es/upload/REV\%20TABONA/19\%20-\%20201112/Tabona\%2019\%20(2011-12)\%20web.pdf 